\title{
The reduction of the reaction torque of a straight four-cylinder four-stroke engine
}

\begin{abstract}
The paper presents both the exact and simplified relations on the course of the reaction torque of a single and multicylinder engine, which is transmitted to the vehicle frame or foundation. The formula for the distance between the balance shafts along the vertical axes ensuring a complete elimination of the impact of the forces of inertia on the course of the reaction torque in four-stroke four-cylinder engines is derived in the paper. The criteria for selecting the optimum value of the distance are also derived in the paper. The dependence of the optimum value of the distance on the state of the engine operation and design parameters of the vehicle propulsion system is indicated in the paper. The paper proposes the selection of the optimum shafts distance, for a given type of vehicle, in areas of the engine most frequently used operating states.
\end{abstract}

Key words: IC engines, crank assembly, reaction torque, balancing

\section{Redukcja momentu reakcyjnego silnika rzędowego czterosuwowego czterocylindrowego}

W pracy przedstawiono zarówno dokładne jak i uproszczone zależności określające przebieg momentu reakcyjnego silnika, jedno $i$ wielocylindrowego, przenoszonego na ramę pojazdu lub fundament. Wyprowadzono zależność na wartość przesunięcia wałków wyrównoważajacych zapewniająca całkowite wyeliminowanie wpływu sił bezwładności na przebieg momentu reakcyjnego w silnikach czterosuwowych czterocylindrowych. Wprowadzono kryteria doboru optymalnej wielkości przesunięcia watków wyrównoważajacych. Wskazano na zależność optymalnej wartości przesunięcia od stanu pracy silnika i parametrów konstrukcyjnych układu napędowego. Zaproponowano dobór optymalnej wartości dla danego typu samochodu w obszarach, w których silnik najczęściej pracuje.

Słowa kluczowe: silniki spalinowe, mechanizm korbowy, moment reakcyjny, wyrównoważanie

\section{Introduction}

For many years, some automobile companies have used balance shafts of the second order inertia forces in fourcylinder four-stroke engines [1, 2, 3, 4, 5, 6]. Work [9] was also devoted to this issue. In many engine designs the balance shafts are located within lateral symmetry but at different heights above the crankshaft such as in the engines of Lancia Delta Integrale and Porsche 944 as well as other designs such as those implemented by Ford and Honda (the balance shafts are placed at the same height). None of the available literature and company materials explains the reasons for the balance shafts location at different heights and the ways of selection of the difference of the optimum height.

The aim of this study was, therefore, to analyze the reaction torque of the engine in order to determine the maximum distance between the balance shafts in four-cylinder fourstroke engines measured along the vertical axes. This was done with a view to eliminate the impact of the inertia forces on the course of the reaction torque and suggest approaches to determine the optimum value of this distance. In a specific case, the optimum value of the distance is in fact dependent on the design parameters of the engine and the vehicle.

\section{Engine reaction torque}

\subsection{Accurate mathematical relationships}

The engine reaction torque depends primarily on the gas forces and the inertia forces in the reciprocating motion.

\section{Wstęp}

Od szeregu lat niektóre firmy samochodowe stosują w silnikach czterocylindrowych czterosuwowych wałki wyrównoważające siły bezwładności drugiego rzędu [1, 2, 3, 4, $5,6]$. Temu zagadnieniu była również poświęcona praca [9]. W wielu rozwiązaniach konstrukcyjnych osie wałków wyrównoważajacych są umieszczane na różnych wysokościach w stosunku do osi obrotu wału korbowego, np. w silnikach samochodów Lancia Delta Integrale i Porsche 944. W innych konstrukcjach np. w samochodach firm Ford, Honda wałki wyrównoważające umieszczone są na tej samej wysokości. Brak w dostępnej literaturze silnikowej i materiałach firmowych wyjaśnienia powodów przesunięcia tych wałków oraz sposobów doboru jego wielkości.

Celem niniejszej pracy była zatem analiza przebiegu momentu reakcyjnego silnika i określenie maksymalnego przesunięcia osi wałków wyrównoważających w silnikach czterocylindrowych czterosuwowych eliminującego wpływ sił bezwładności na przebieg momentu reakcyjnego oraz zaproponowanie sposobu podejścia do określenia optymalnej wartości tego przesunięcia. Konkretna, optymalna wartość przesunięcia jest bowiem zależna od parametrów konstrukcyjnych silnika i pojazdu.

\section{Moment reakcyjny silnika}

\subsection{Dokładne zależności}

Wartość momentu reakcyjnego silnika zależy przede wszystkim od sił gazowych i sił bezwładności w ruchu po- 
In addition to the above-mentioned forces the geometric parameters of the crank assembly as well as the number and configuration of cylinders also affect the course of the torque. It is obvious that the geometrical parameters of the crank assembly affect the reaction torque both directly and through the inertia forces. This torque is transmitted to the frame of the vehicle through the engine mounting system and influences the magnitude of vibration of the whole vehicle.

The distribution of forces in the crank assembly, reduced to a dual-mass one, consisting of masses $m_{p}$ and $m_{0}$ engaged in the reciprocating and rotating motions respectively, are shown in Figure 1.

It follows from Fig. 1 that the vector of reaction torque $\mathbf{M}_{\mathrm{Ni}}$ can be expressed by the following relationship:

while

$$
\mathbf{M}_{\mathrm{Ni}}=\mathbf{s}_{\mathrm{i}} \times \mathbf{N}_{\mathrm{i}}
$$

$$
\mathrm{s}_{\mathrm{i}}=\mathrm{s}_{\mathrm{i}} \cdot \mathrm{k}_{\mathrm{y}}
$$

where: $\mathbf{N}_{i}-$ normal force of $i$-th cylinder, $s_{i}-$ distance from the center of mass $m_{p}$ to the axis of the crankshaft rotation, $\mathrm{k}_{\mathrm{y}}$ - versor along the $\mathrm{y}$ axes.

After development of relation (1) we get:

while:

$$
\mathrm{M}_{\mathrm{Ni}}=\mathrm{R} \Phi\left(\alpha+\delta_{\mathrm{i}}\right) \mathbf{k}_{\mathrm{y}} \times \mathbf{P}_{\mathrm{i}}\left(\alpha+\delta_{\mathrm{i}}\right)
$$

$$
\begin{aligned}
& \Phi\left(\alpha+\delta_{i}\right)=\sin \left(\alpha+\delta_{i}\right)+ \\
& \frac{\lambda \sin 2\left(\alpha+\delta_{i}\right)}{2 \sqrt{1-\lambda^{2} \sin ^{2}(\alpha+\delta)_{i}}}
\end{aligned} ; \lambda=\frac{\mathrm{R}}{\mathrm{L}}
$$

where: $\mathrm{R}$ - crankshaft throw, L - length of connecting rod, $\alpha$ - angle of crank travel from the cylinder axes, $\lambda$ - ratio between crank radius and length of connecting rod, $\delta$ - angle between cranks of the first and ith cylinder.

$$
\begin{gathered}
\mathbf{P}_{\mathrm{i}}=\mathbf{P}_{\mathrm{gi}}+\mathbf{P}_{\mathrm{bi}} \\
\delta_{\mathrm{i}}=(\mathrm{i}-1) \frac{4 \pi}{\mathrm{z}},
\end{gathered}
$$

where: $\mathbf{P}_{\mathrm{i}}-$ total force acting on the piston, $\mathbf{P}_{\mathrm{gi}}-$ force of gas pressure in the $\mathrm{i}$-th cylinder, $\mathbf{P}_{\mathrm{bi}}-$ inertia force in the $\mathrm{i}$-th cylinder, $\mathrm{z}$ - number of cylinders.

The value of the reaction torque vector component derived from the forces of inertia in the reciprocating motion of a cylinder can be represented by the following equation:

$$
\mathrm{M}_{\mathrm{Ni}}=\mathrm{m}_{\mathrm{p}} \mathrm{R}^{2} \omega^{2} \psi\left(\alpha+\delta_{\mathrm{i}}\right) \Phi\left(\alpha+\delta_{\mathrm{i}}\right)
$$

while:

$$
\begin{aligned}
& \psi\left(\alpha+\delta_{i}\right)=\cos \left(\alpha+\delta_{i}\right)+ \\
& \frac{\lambda \cos 2\left(\alpha+\delta_{i}\right)}{\sqrt{1-\lambda^{2} \sin ^{2}\left(\alpha+\delta_{i}\right)}}+\frac{\lambda^{3} \sin ^{2} 2\left(\alpha+\delta_{i}\right)}{4 \sqrt{\left[1-\lambda^{2} \sin ^{2}\left(\alpha+\delta_{i}\right)\right]^{3}}}
\end{aligned}
$$

stępowo-zwrotnym. Na przebieg tego momentu, poza wyżej wymienionymi siłami, mają wpływ parametry geometryczne mechanizmu korbowego oraz liczba i układ cylindrów. Jest oczywiste, że parametry geometryczne mechanizmu korbowego wpływają na moment reakcyjny zarówno bezpośrednio jak i poprzez siły bezwładności. Moment ten przenosi się na ramę pojazdu poprzez układ mocowania silnika i wpływa na wielkość drgań całego pojazdu.

Rozkład sił w mechanizmie korbowym, sprowadzonym do układu dwumasowego składającego się $z$ mas $m_{p}$ i m wykonujących odpowiednio ruch postępowo-zwrotny $\mathrm{i}$ obrotowy, pokazano na rysunku 1.

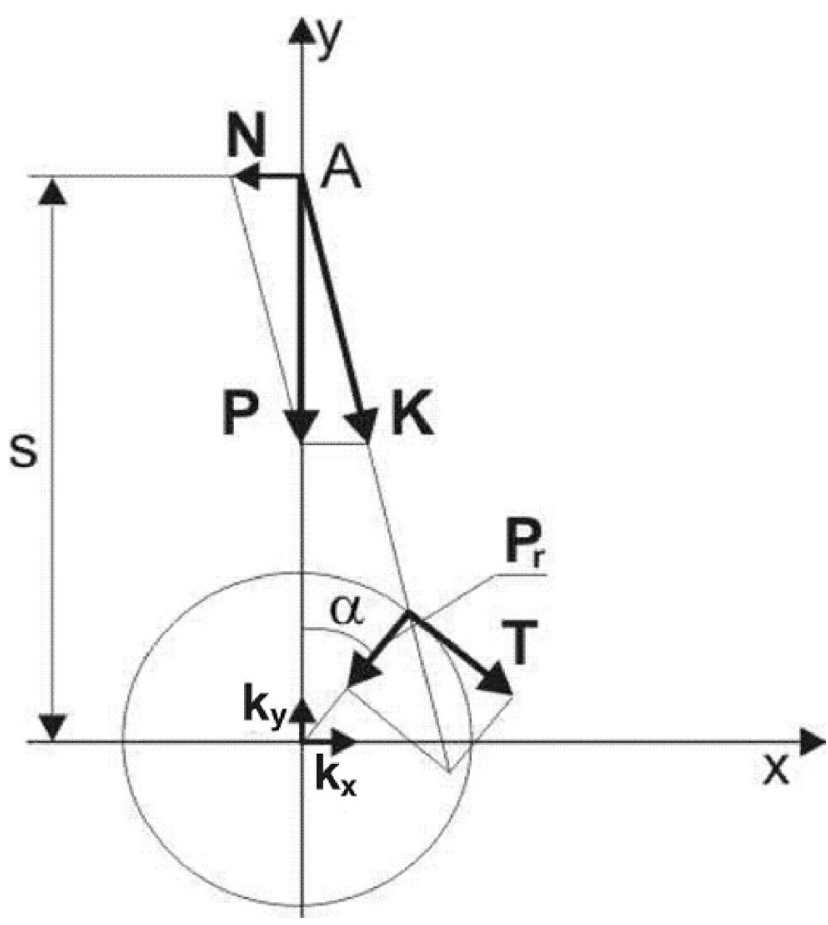

Fig. 1. Forces acting in the crank assembly Rys. 1. Rozkład sit w mechanizmie korbowym

Jak wynika z rysunku 1 wektor momentu reakcyjnego silnika $\mathrm{M}_{\mathrm{Ni}}$, wyraża zależność (1), przy czym

$$
\mathrm{s}_{\mathrm{i}}=\mathrm{s}_{\mathrm{i}} \cdot \mathrm{k}_{\mathrm{y}}
$$

gdzie: $\mathbf{N}_{i}$ - siła normalna i-tego cylindra, $\mathrm{s}_{\mathrm{i}}$ - odległość środka masy mp od osi obrotu wału korbowego, $\mathrm{k}_{\mathrm{y}}$ - wersor wzdłuż osi y.

Po rozwinięciu zależności (1) otrzymamy (2), przy $\operatorname{czym}(3)$,

gdzie: $\mathrm{R}$ - promień wykorbienia, $\mathrm{L}$ - długość korbowodu, $\alpha$ - kąt obrotu wału korbowego, $\lambda$ - parametr mechanizmu korbowego, $\delta$ - kąt pomiędzy wykorbieniem pierwszego a i-tego cylindra.

Przyjmując (4) oraz (5),

gdzie: $\mathbf{P}_{\mathrm{i}}-$ siła tłokowa, $\mathbf{P}_{\text {gi }}-$ siła gazowa w i-tym cylindrze, $\mathbf{P}_{b i}$ - siła bezwładności w i-tym cylindrze, $\mathrm{z}$ - liczba cylindrów. 
For a multi-cylinder engine containing $\mathrm{z}$ cylinders the reaction torque of the inertia forces in reciprocating motion shows the following relationship:

$$
\mathrm{M}_{\mathrm{N}}{ }^{\mathrm{b}}=\mathrm{m}_{\mathrm{p}} \mathrm{R}^{2} \omega^{2} \sum_{\mathrm{i}=1}^{\mathrm{z}} \psi\left(\alpha+\delta_{\mathrm{i}}\right) \Phi\left(\alpha+\delta_{\mathrm{i}}\right)
$$

In the case of a four-cylinder four-stroke engine relationship (6), after taking into account relations (3) and (7), can be converted to the following form:

$$
\begin{aligned}
& \mathrm{M}_{\mathrm{N}}^{\mathrm{b}}=2 \mathrm{~m}_{\mathrm{p}} \mathrm{R}^{2} \omega^{2}[\sin 2 \alpha+ \\
& \left.+\frac{1}{2} \frac{\lambda^{2} \sin 4 \alpha}{\left(1-\lambda^{2} \sin ^{2} \alpha\right)}+\frac{\lambda^{4} \sin ^{3} 2 \alpha}{4\left(1-\lambda^{2} \sin ^{2} \alpha\right)^{2}}\right]
\end{aligned}
$$

An example of the reaction torque of a car engine versus angle $\alpha$ of the crank travel, generated by the forces of inertia, is shown in Fig. 2.

\subsection{Approximate relationships}

For the purposes of the analysis of the effect of the inertia forces on the course of the engine torque and, therefore, also on the course of its reaction torque, mathematical dependence (9) shall be presented in another form. Taking into account relation (6) the simplified expressions for the functions of $\psi\left(\alpha+\delta_{i}\right)$ and $\Phi\left(\alpha+\delta_{i}\right)$ obtained by the decomposition of the root expressions in a power series we get the following form of the relation for the engine torque coming from one cylinder $[7,8]$ :

$$
\begin{aligned}
& \mathrm{M}_{\mathrm{N}}{ }^{\mathrm{b}}=\mathrm{m}_{\mathrm{p}} \mathrm{R}^{2} \omega^{2}\left(\frac{1}{4} \lambda \sin \alpha-\frac{1}{2} \sin 2 \alpha-\frac{3}{4} \lambda \sin 3 \alpha-\right. \\
& \left.-\frac{1}{4} \lambda^{2} \sin 4 \alpha+\frac{5}{32} \lambda^{3} \sin 5 \alpha+\frac{3}{32} \lambda^{4} \sin 6 \alpha+\ldots\right) .
\end{aligned}
$$

Wartość składowej wektora momentu reakcyjnego pochodzącej od sił bezwładności w ruchu postępowo-zwrotnym jednego cylindra można przedstawić za pomocą zależności (6), przy czym (7).

Dla silnika wielocylindrowego o liczbie cylindrów z moment reakcyjny sił bezwładności od mas w ruchu postępowo-zwrotnym przedstawia zależność (8).

W przypadku silnika czterocylindrowego czterosuwowego zależność (6), po uwzględnieniu zależności (3) i (7), można przekształcić do postaci (9).

Przykładowy przebieg momentu reakcyjnego silnika samochodowego pochodzącego od sił bezwładności, w zależności od kąta obrotu wału korbowego $\alpha$ przedstawiono na rysunku 2.

\subsection{Zależności przybliżone}

Dla celów analizy wpływu sił bezwładności na przebieg momentu obrotowego silnika, a w związku z tym również na przebieg momentu reakcyjnego, zależność (9) przedstawia się w innej postaci. Uwzględniając mianowicie w zależności (6) uproszczone wyrażenia na funkcje i uzyskane w wyniku rozkładu wyrażeń pierwiastkowych w szereg potęgowy, otrzymuje się postać zależności na moment reakcyjny silnika pochodzący od jednego cylindra [7, 8] (10).

Analiza zależności (10) w odniesieniu do wielocylindrowych silników rzędowych pozwala na sformułowanie następujących wniosków:

- w silnikach dwusuwowych i w silnikach czterosuwowych o nieparzystej liczbie cylindrów na przebieg momentu reakcyjnego silnika wpływają następujące harmoniczne momentu pochodzącego od sił bezwładności (11),

- w silnikach czterosuwowych o parzystej liczbie cylindrów na przebieg momentu reakcyjnego mają wpływ harmoniczne pochodzącego od sił bezwładności o rzędzie określonym według formuły (12).
The analysis of relationship (10) with respect to multi-cylinder engines allows the following conclusions:

- in all two-stroke engines and four-stroke ones with an odd number of cylinders the following harmonics originating from the moment of inertia forces affect the engine torque:

$$
\mathrm{z} \cdot \mathrm{k}, \mathrm{k}=1,2,3, \ldots
$$

- in four-stroke engines with an even number of cylinders the harmonics of the order defined by the following formula, originating from the moment of inertia forces, affect the engine torque:

$$
1 / 2 \mathrm{z} \cdot \mathrm{k}, \mathrm{k}=1,2,3, \ldots
$$

Taking the above into consideration relation (10), for a four-stroke four-cylinder engine, can be transformed to the form as below:

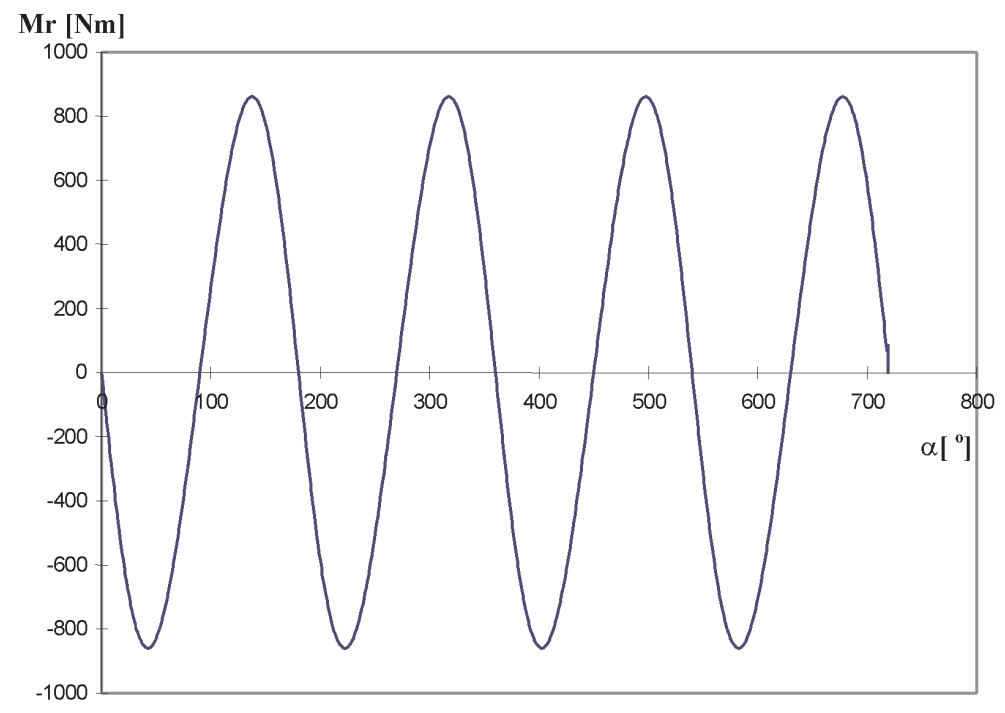

Fig. 2. Reaction torque of a car engine generated by the inertia forces for $m_{p}=0.6$, $\lambda=0.3$ and $\mathrm{n}=6400 \mathrm{rpm}$

Rys. 2. Przyktadowy przebieg momentu reakcyjnego silnika pochodzacego od sit bezwładności dla $m_{p}=0,6, \lambda=0,3$ i $n=6400 \mathrm{obr} / \mathrm{min}$ 


$$
\begin{aligned}
& M_{N}{ }^{b}=2 m_{p} R^{2} \omega^{2}(\sin 2 \alpha+ \\
& \left.+\frac{1}{2} \lambda^{2} \sin 4 \alpha-\frac{1}{4} \lambda^{4} \sin 6 \alpha+\ldots\right) .
\end{aligned}
$$

During the analysis of the effect of the inertia forces on the torque only the first three harmonics are usually taken into account. This simplification means that the reaction torque of a four-stroke four-cylinder engine, which comes from these forces, would be represented by the following simple relationship:

$$
\mathrm{M}_{\mathrm{N}}^{\mathrm{b}}=2 \mathrm{~m}_{\mathrm{p}} \mathrm{R}^{2} \omega^{2} \sin 2 \alpha .
$$

But we must remember that the error made due to this simplification increases with the value of the $\lambda$ parameter.

The relative error $\mathrm{B}$ made when determining the maximum reaction torque on the grounds of relationship (14) instead of (9), as a function of $\lambda$, is shown by the formula:

$$
\mathrm{B}=\frac{\left|\frac{\lambda^{2} \sin 4 \alpha}{1-\lambda^{2} \sin ^{2} \alpha}+\frac{\lambda^{4} \sin ^{3} 2 \alpha}{2\left(1-\lambda^{2} \sin ^{2} \alpha\right)^{2}}\right|_{\max }}{\left|2 \sin 2 \alpha+\frac{\lambda^{2} \sin 4 \alpha}{1-\lambda^{2} \sin ^{2} \alpha}+\frac{\lambda^{4} \sin ^{3} 2 \alpha}{2\left(1-\lambda^{2} \sin ^{2} \alpha\right)^{2}}\right|_{\max }}
$$

The course of error $\mathrm{B}$, for $\lambda \in<0,0.5>$, determined on the grounds of relation (15), is presented in Fig. 3.

It follows from Fig. 3 that the error values are raising very rapidly and exceed $14 \%$ for maximum $\lambda$ values encountered in practice. In car engines, however, these values typically do not exceed $6 \%$.

\section{The balance shafts offset}

The impact of the second order component expressed by relation (14) on the reaction torque can be reduced by shifting the shafts balancing the second order inertia forces along the vertical axes. This arrangement of the balance shafts is shown in Fig. 4. As a result of the application of dual balance shafts, according to Taylor-Lanchester concept (Fig. 4), the second order inertia forces will be balanced if the following condition is met:

$$
\mathrm{nm}_{\mathrm{c}} \mathrm{R}^{\prime}=\mathrm{m}_{\mathrm{p}} \mathrm{R} \lambda
$$

where: $m_{c}-$ mass of one counterweight, $n-$ number of counterweights.

The left side of relation (16) is the static moment of the counterweights located on the balancing shafts. Consequently, the following equation is true, the fulfillment of which constitutes the sufficient condition for the total reduction of the effect of the second order inertia forces on the course of the reaction torque transmitted to the vehicle frame.

$$
\frac{1}{2} m_{p} R \lambda(2 \omega)^{2} h \sin 2 \alpha=2 m_{p} R^{2} \omega^{2} \sin 2 \alpha
$$

hence:
W związku z powyższym zależność (10) dla silnika czterosuwowego czterocylindrowego sprowadza się do postaci (13).

Podczas analizy wpływu sił bezwładności na przebieg momentu obrotowego zwykle uwzględnia się tylko trzy pierwsze harmoniczne momentu. Takie uproszczenie oznacza, że moment reakcyjny silnika czterocylindrowego czterosuwowego, pochodzący od tych sił, wyrażałaby zależność (14).

Pamiętać jednak należy, że błąd jaki popełniamy przy takim uproszczeniu rośnie wraz z wartością parametru mechanizmu korbowego $\lambda$.

Błąd względny popełniany przy wyznaczaniu maksymalnej wartości momentu reakcyjnego na podstawie zależności (14) zamiast (9) w funkcji $\lambda$, przedstawia zależność (15).

Przebieg błędu B dla $\lambda \in<0,0.5>$, wyznaczony na podstawie zależności (15), przedstawiono na rysunku 3.

Jak wynika z rysunku 3 wartości błędu bardzo szybko rosną i przekraczają 14\% dla największych wartości parametru $\lambda$ spotykanych w praktyce. W silnikach samochodowych natomiast wartości te zazwyczaj nie przekraczają $6 \%$.

\section{Przesunięcie osi walków wyrównoważających}

Wpływ składowej drugiego rzędu wyrażonej zależnością (14) na przebieg momentu reakcyjnego można zredukować do zera w wyniku przesunięcia o wielkość h osi wałków wyrównoważających siły bezwładności drugiego rzędu. Taki układ wałków wyrównoważających został przedstawiony na rysunku 4. W wyniku zastosowania dwóch wałków wyrównoważających, zgodnie z układem Taylora-Lanchestera (rys. 4), siły bezwładności drugiego rzędu zostaną wyrównoważone jeśli będzie spełniony warunek (16),

gdzie: $m_{c}-$ wartość jednej przeciwmasy, $n$ - liczba przeciwmas.

Lewa strona zależności (16) oznacza moment statyczny przeciwmas znajdujących się na wałkach wyrównoważają-

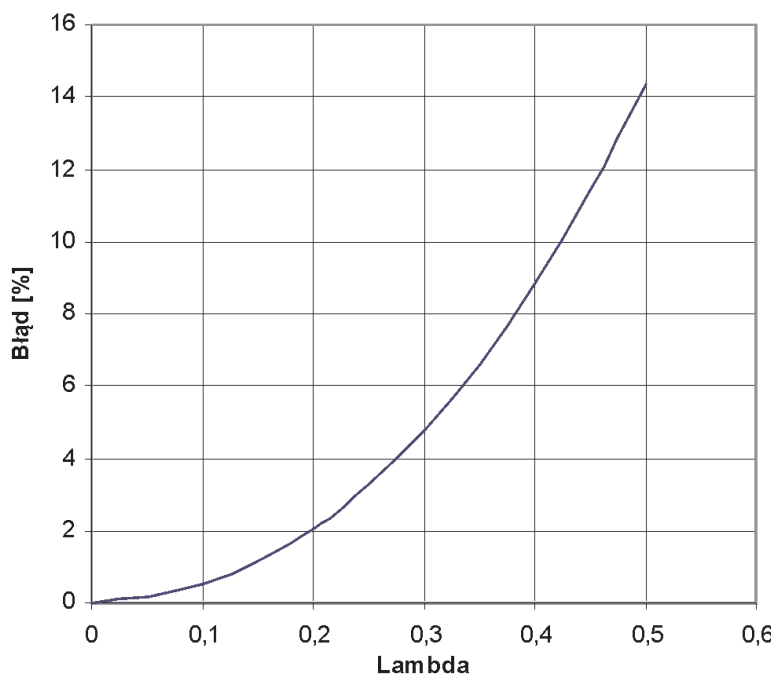

Fig. 3. Relative error B as a function of $\lambda$

Rys. 3. Btąd względny $w$ wyznaczaniu wartości momentu reakcyjnego jako funkcja parametru $\lambda$ 


$$
\mathrm{h}=\frac{\mathrm{R}}{\lambda}=\frac{\mathrm{S}}{2 \lambda}
$$

while $\mathrm{S}$ in relation (18) is the piston stroke. As mentioned in Chapter 2, the course of the engine torque, as a function of angle of crank travel, is the result of cumulative impacts of the gas pressure and inertia forces in a reciprocating motion. The value of the gas pressure forces, and therefore their impact on the course of the reaction torque, is primarily a function of load and to a lesser extent a function of speed. The course of the reaction torque can be changed by acting on its component coming from the inertia forces through the choice of the distance $\mathrm{h}$ between the balance shafts (Fig. 4). The complete reduction of the impact of this component may increase rather than decrease the value of the absolute maximum of the reaction torque. The selection of the optimum distance $\mathrm{h}_{\mathrm{opt}}$, enabling favorable change in the course of the reaction torque, requires an adoption of an appropriate optimization

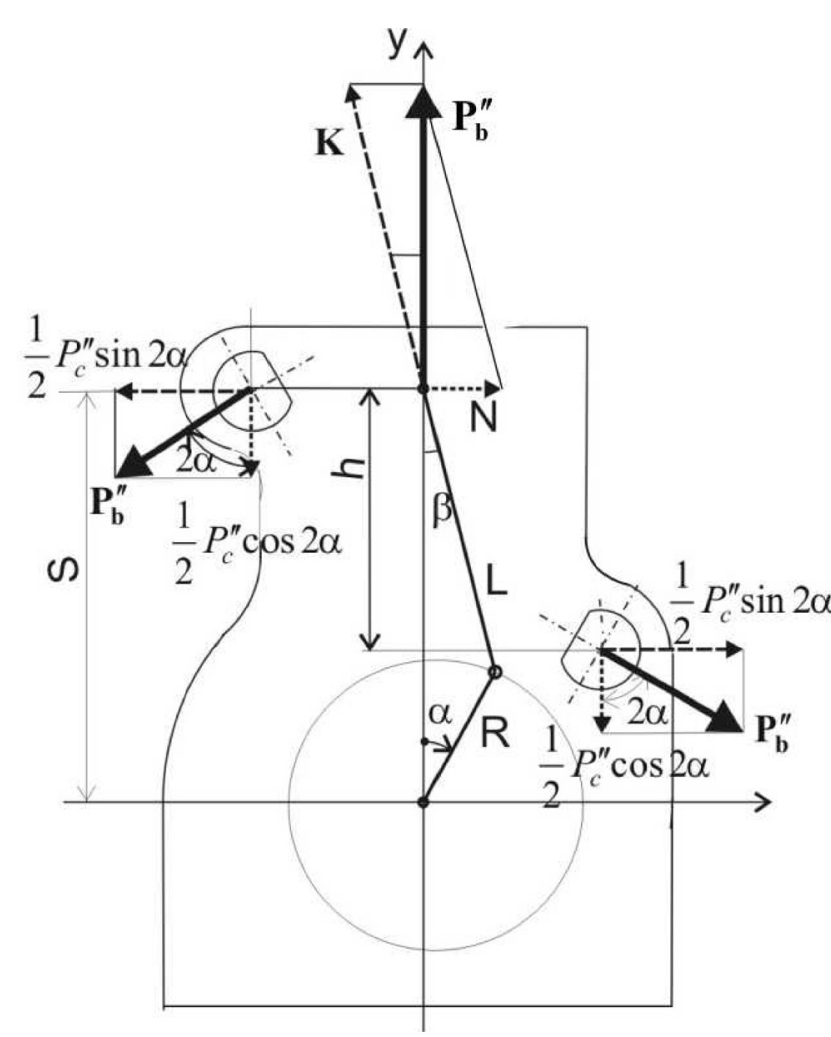

Fig. 4. Arrangement of the balance shafts Rys. 4. Układ wałków wyrównoważajacych cych. Wobec powyższego słuszne jest następujące równanie, spełnienie którego stanowi wystarczający warunek całkowitego zniesienia wpływu sił bezwładności drugiego rzędu na przebieg momentu reakcyjnego silnika przenoszonego na ramę pojazdu (17), a stąd otrzymujemy (18),

przy czym S w zależności (18) oznacza skok tłoka.

Jak wspomniano w rozdziale 2 przebieg momentu reakcyjnego silnika, jako funkcja kąta obrotu wału korbowego, jest wynikiem łącznych oddziaływań sił gazowych i sił bezwładności w ruchu postępowo-zwrotnym. Wartość sił gazowych, a w związku z tym ich wpływ na przebieg momentu reakcyjnego jest przede wszystkim funkcją obciążenia (wielkości dawki paliwa) a w mniejszym stopniu funkcją prędkości obrotowej.

Przebieg momentu reakcyjnego silnika można zmieniać oddziaływując na składową momentu pochodzącą od sił bezwładności poprzez dobór przesunięcia wałków wyrównoważających h. Całkowite zniesienie wpływu składowej momentu od sił bezwładności, zamiast zmniejszyć, może spowodować zwiększenie maksymalnej wartości momentu reakcyjnego. Dobór odległości h, umożliwiającej korzystną zmianę przebiegu momentu reakcyjnego silnika, wymaga criterion. From the standpoint of the loads carried by the frame of the vehicle the following equivalent criteria could be proposed:

$$
\begin{aligned}
& \left(h_{o p t} \in\left\langle 0 ; \begin{array}{c}
R \\
L
\end{array}\right)\right):\left\{\begin{array}{c}
M_{N}(h)_{\max }-M_{N}(h)_{\min } \\
M_{N s r}
\end{array}=\min \right\} \\
& \left(h_{o p t} \in\left\langle 0 ; \frac{R}{L}\right\rangle\right):\left\{, \quad>\frac{M_{N}(h)_{\max }}{M_{N s r}}=\min \right\}
\end{aligned}
$$

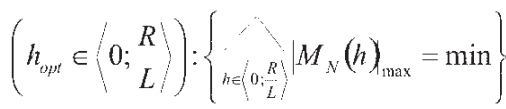

where: $\mathrm{M}_{\mathrm{Nmax}}-$ absolute maximum of the torque, $\mathrm{M}_{\mathrm{Nmin}}$ absolute minimum of the torque, $\mathrm{M}_{\mathrm{Nsrr}}$ - mean value of the torque.

The optimum distance $h_{\text {opt }}$ between the shafts is different for each point of the engine operation defined by its load and speed. For this reason, the distance $h$ is optimized in the area of loads and speeds and is expected to occur most often in normal vehicle operation. For this purpose it is necessary to know the reciprocating masses, and the engine indicator przyjęcia odpowiedniego kryterium optymalizacyjnego. Z punktu widzenia wartości obciążeń przenoszonych przez ramę pojazdu można by wprowadzić następujące, równoważne kryteria (19)-(21),

gdzie: $M_{N \max }-$ maksimum absolutne momentu, $M_{N \min }$ - minimum absolutne momentu, $\mathrm{M}_{\mathrm{N} s ́ r}$ - wartość średnia momentu.

Optymalna odległość $h_{\text {opt }}$ jest inna w poszczególnych punktach pola pracy silnika określonych wartością momentu obrotowego i prędkości obrotowej. Z tego względu wielkość tę optymalizuje się dla najczęściej spotykanych warunków eksploatacji samochodu. Do tego celu niezbędna jest znajomość mas w ruchu postępowo-zwrotnym oraz dysponowanie wykresami indykatorowymi silnika. Z uwagi na to, że maksymalne wartości momentu obrotowego wykorzystywane są w silnikach samochodowych stosunkowo rzadko, nie dobiera się odległości wałków h dla maksymalnej dawki paliwa. Warto w tym miejscu zauważyć także, że przesunięcie wałków wyrównoważajacych ma znaczenie dopiero po przekroczeniu pewnej prędkości obrotowej silnika, zazwyczaj powyżej 2800 obr/min. Z analizy konstrukcji 
diagrams. Because of the fact that maximum torque values are rarely used in car engines, $h_{\text {opt }}$ is not chosen for maximum loads of the engine. It should also be noted that the location of the balance shafts at different heights is important only after exceeding a certain engine speed, usually above $2800 \mathrm{rpm}$. It follows from the design analyses of the engines fitted with balance shafts that in the case of the engines of Lancia Delta Integralne, Porsche 944 and Mitsubishi the h value is close to the piston stroke. For example, in the engine of Mitsubishi Motors Corporation the distance $\mathrm{h}$ amounts to:

$$
\mathrm{h}=0.7 \mathrm{~L}=\frac{0.35}{\lambda} \mathrm{S}
$$

In other design solutions (Ford, Honda), balance shafts are placed at the same height. In this case they do not have any effect on the reaction torque of the engine.

\section{Concluding remarks}

It is well known that in four-stroke four-cylinder engines the inertia forces of the second order are not balanced. In order to fully balance the engine, thus, reduce the load of the screws fixing the engine to the vehicle frame, reduce body vibration and noise, some companies use two balance shafts rotating in opposite directions with an angular velocity twice that of the crankshaft. There are also solutions in which the balance shafts are not placed on the same level, but are shifted against each other along the vertical axes. The purpose of this is to reduce the engine reaction torque transmitted to the vehicle frame. The maximum shift of the axis of the balance shafts fully reducing the effect of the inertia forces on the course of the engine torque is determined by relation (18). A full reduction of the impact of the inertia forces on the engine torque is not favorable. In practice, the optimum value of $h$ is chosen for the engine loads and speeds expected to be most frequently occurring in normal vehicle operation. Therefore the $h$ values used by the engine designers are much smaller than the maximum and not much different from the value of the piston stroke.

Paper reviewed/Artykut recenzowany

Mr. Ryszard Mosakowski, DEng. - doctor in the Mechanical Engineering Faculty at Gdańsk University of Technology.

Dr inż Ryszard Mosakowski - adiunkt na Wydziale Mechanicznym Politechniki Gdańskiej.

e-mail: rmosakow@sunrise.pg.gda.pl silników wyposażonych w wałki wyrównoważające wynika, że w przypadku silników samochodów Lancia Delta Integralne, Porsche 944 i Mitsubishi przesunięcie osi wałków wyrównoważających jest zbliżone do wartości skoku tłoka. Na przykład w silniku firmy Mitsubishi Motors odległość ta wynosi (23):

W innych konstrukcjach (Ford, Honda) wałki wyrównoważające umieszczone są w jednej płaszczyźnie. W tym przypadku nie mają one żadnego wpływu na moment reakcyjny silnika.

\section{Uwagi końcowe}

Powszechnie wiadomo, że w silnikach czterosuwowych 4-cylindrowych nie są wyrównoważone siły bezwładności drugiego rzędu. W celu ich wyrównoważenia, a tym samym zmniejszenia m.in. obciążenia śrub mocujących silnik do ramy pojazdu, wibracji nadwozia i emisji hałasu, niektóre firmy stosują dwa wałki wyrównoważające obracające się w kierunkach przeciwnych z prędkością kątową dwa razy większą niż wał korbowy. Są także rozwiązania, w których wałki wyrównoważajace nie są umieszczone na tym samym poziomie lecz są przesunięte względem siebie o pewną wielkość. Celem takiego przesunięcia jest zmniejszenie momentu reakcyjnego silnika przenoszonego na ramę pojazdu. Maksymalne przesunięcie osi wałków wyrównoważających, znoszące całkowicie wpływ sił bezwładności na moment reakcyjny, określa zależność (18). Całkowite zniesienie wpływu sił bezwładności na moment reakcyjny nie jest jednak korzystne. W praktyce optymalne wartości h dobiera się dla stanów pracy silnika najczęściej występujących w eksploatacji. Dlatego stosowane przez firmy samochodowe wielkości h są znacznie mniejsze niż maksymalne i niewiele różnią się od wartości skoku tłoka.

\section{Bibliography/Literatura}

[1] Borkowski J.: Lancia Thema. Auto Technika Motoryzacyjna. $\mathrm{Nr}$ 6/1985.

[2] Silvers R., Pilgrim R.: Schwingungstechnisch-akustische Massnahmen bei der Entwicklung des Porsche 944-Motors. ATZ, nr 11, 1981.

[3] Szelichowski S.: Samochody rajdowe Lancia i Fiat. Auto Technika Motoryzacyjna, $\mathrm{nr}$ 4/1990.

[4] Szelichowski S.: Saab 9000 - gość ze Skandynawii. Auto Technika Motoryzacyjna, nr 4/1990.

[5] Jaźwiński T.: Nowa moc. Auto motor i sport, nr 4, 1998.

[6] SAAB 9000. Auto Technika Motoryzacyjna, nr 2, 1997.

[7] Jędrzejowski J.: Mechanika układu korbowego. WKiŁ, Warszawa 1973.

[8] Jędrzejowski J.: Obliczanie tłokowego silnika spalinowego. WNT Warszawa 1969.

[9] Mosakowski R., Konaszewski S.: Dobór optymalnego momentu statycznego wałków wyrównoważających w silniku rzędowym czterosuwowym czterocylindrowym. Archiwum Motoryzacji nr $5 / 2000$ 